Post print of: Spectroscopy Letters, volume 45, 2 (2012), pages 109-113

\title{
Moganite in the chalcedony varieties of continental cherts (Miocene, Madrid Basin Spain)
}

$M^{a}$. Ángeles Bustillo ${ }^{1}$, José Luis Pérez-Jiménez ${ }^{1,2}$, Ana $M^{a}$ Alonso-Zarza ${ }^{3}$ and Marta Furio ${ }^{1}$. ${ }^{1}$ Dpto. de Geología. Museo Nacional de Ciencias Naturales, CSIC. c/ José Gutiérrez Abascal, n², 28006-Madrid, Spain. ²Current address: Centro Tecnológico de Repsol, 28931Móstoles, Spain. ${ }^{3}$ Dpto. de Petrología y Geoquímica, Facultad de Geológicas, Instituto de Geociencias (UCM-CSIC), Universidad Complutense de Madrid, 28040-Madrid, Spain.

Address correspondence to Dr. Ma Ángeles Bustillo, Dpto. de Geología, Museo Nacional de Ciencias Naturales- CSIC, c/ José Gutiérrez Abascal, n²2, Zip code 28006,Madrid, Spain. E-mail: abustillo@mncn.csic.es

ABSTRACT Varieties of chalcedony (calcedonite, quartzine and lutecite) and other optical micro- and crypto-crystalline textures of quartz and opal, from Miocene silcretes of the Madrid Basin were studied using a Thermo Fisher DXR Raman microscope. The microscope has a point-and-shoot Raman capability of $1-\mu \mathrm{m}$ spatial resolution, and was coupled with a standard optical microscope. Our results show that all the varieties of chalcedony can have a composite Raman spectrum of both quartz and moganite. The spectra are independent of the chalcedony origin by ageing, direct replacement or cementation processes. Moganite was absent only in some calcedonite cements. The presence of moganite is independent of the surface sedimentary setting of the host rocks in which the silcretes are formed.

KEYWORDS: chalcedony, moganite, silcretes, chert, Micro-Raman 


\section{INTRODUCTION}

The Miocene deposits of the Madrid Basin contain abundant diagenetic silica rocks. The great variation in the petrology of these rocks reflects their main formation mechanism, which is replacement of previous rocks, including paleosols. Silica rocks in the Madrid basin were formed in a variety of near-surface sedimentary settings. ${ }^{[1]}$ Many of these silica rocks, considered silcretes, are defined as cherts and opaline cherts, with a variety of quartz and opal textures under thin section in optical microscopy. Data of Raman analysis of silcretes from Kalahari desert showed that moganite is present in the majority of them. ${ }^{[2]}$

Moganite is considered a silica polymorph; its crystal structure can be described as derived from quartz by twinning in accordance with the Brazil-law at unit cell scale. ${ }^{[3]}$ The structure of chalcedony is composed of alternating quartz and moganite domains, of varied sizes, in three dimensions. Moganite is to some degree thermodynamically unstable, and with time,

temperature and weathering is dissolved and becomes quartz. ${ }^{[4,5 \text { and } 6]}$ Other unstable silica phases that can appear in the opaline cherts accompanying moganite are opal CT (disordered stacks of $\alpha$ cristobalite and $\alpha$ tridymite-like layers) and opal A (highly disordered silica, amorphous). Both can be defined by X-ray diffraction. ${ }^{[7]}$

The moganite/quartz ratio obtained by Raman has been interpreted by authors of various works as an indication of lack of homogeneity of the silica phases in sinters, ${ }^{[8]}$ of diagenesis in sinters, ${ }^{[9]}$ or of recrystallizations (ageing) of agate over time ${ }^{[6]}$ The present work examines and interprets variations in the moganite/quartz ratio obtained in varieties of chalcedony (calcedonite, quartzine, lutecite) and other micro and cryptocrystalline textures of quartz and opal, using micro-Raman and optical microscopy. Data herein were interpreted taking into account the depositional environment of the host rock and the genesis of the silica rocks. Biostratigraphic and paleomagnetic studies of the host rocks of the silcretes attribute an age of Middle Miocene ${ }^{[10]}$ to the rocks. All of our samples can be considered to be of a similar age, thus we can rule out variations in the amount of moganite due to ageing. All samples were formed in near-surface environments. 


\section{OBJECTIVES}

Moganite is a metastable transitory silica polymorph that appears in near-surface silica rocks, but its presence is difficult to determine by a routine standard X-ray diffraction scan, due to the interference with quartz diffraction lines. The main objective of this work is to determine the presence of moganite in silcretes by Micro-Raman. This convenient method allows detection of moganite in silica optical textures that are commonly used in petrological interpretations in Geosciences.

\section{MATERIALS AND METHODS}

Eight samples from six different settings from the Miocene of the Madrid Basin (Figure 1) were selected with varying quartz and opal textures, found in a variety of host rocks (limestones, dolostones, gypsums, mudstones) and formed in various continental environments (palustrine, lacustrine, and soils). After mineralogical and petrological study, by X-ray diffraction and optical microscopy, thin sections of silcretes, defined petrologically as chert and opaline cherts, were chosen and prepared for standard optical microscopy study. In addition to the silica phases, small amounts of dolomite, gypsum or clay minerals were found in most samples. Appropriate zones for micro-Raman analysis were selected by optical microscopy. The different chalcedony varieties studied were: calcedonite (length-fast chalcedony, in which elongation of the fibres is perpendicular to the crystallographic c-axis), quartzine (length-slow chalcedony, in which elongation is parallel), lutecite (another type of length-slow chalcedony, in which the fibre axis is inclined by approximately $30^{\circ}$ ) 


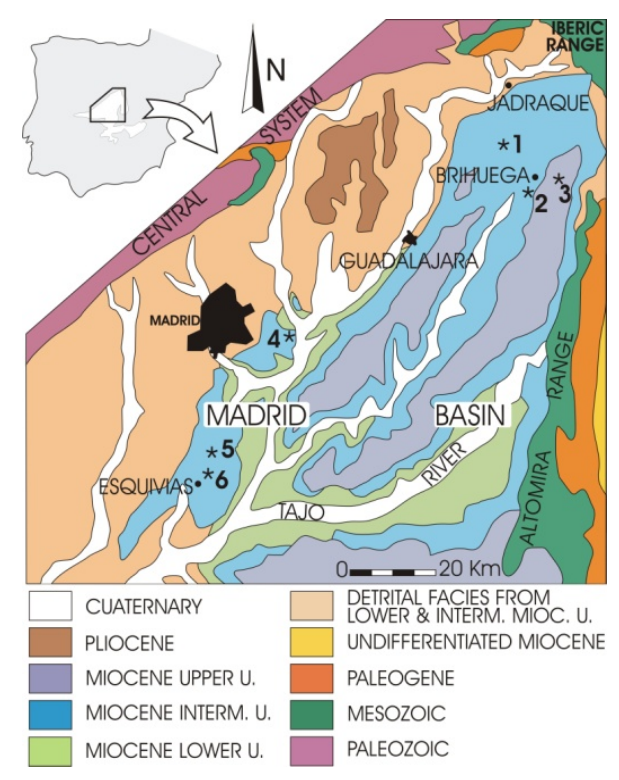

FIGURE 1- Geological map of the Madrid Basin with indication $\left(^{*}\right)$ of the studied outcrops: 1) Muduex: sample MDX-18; 2) Los Yesares: PISCI-3B and CC-2; 3) Brihuega: BRI-12; 4) Casa Montero: CMO-4 and S-4; 5) Cerro Batallones: BAT-74; 6) Esquivias: ESQ-11

A Thermo Fisher DXR Raman microscope, which has a point-and-shoot Raman capability of 1$\mu \mathrm{m}$ spatial resolution, was used with laser source at $532 \mathrm{~nm}$. Small networks of 50-100 x 50-100 $\mu \mathrm{m}$ were analyzed, and a total of 250 spots were obtained for the eight samples. Variations in the moganite/quartz ratio were obtained from the intensity ratios of the main symmetric stretching-bending vibrations of moganite (502 cm-1) and alpha-quartz (465 cm-1) respectively (Figure 2), although the intense band at $465 \mathrm{~cm}-1$ overlaps with a small moganite band at 463 $\mathrm{cm}-1^{[8]}$. This method can provide a measure of the moganite content in relation to quartz, through calibration curves ${ }^{[11]}$, although there may be some problems due to the presence of preferred crystallographic orientations in chalcedony ${ }^{[12]}$. In this study, we limit ourselves to a consideration only of the moganite/quartz ratio, as other authors, cited above, have done. ${ }^{[6,8 \text { and } 9]}$ 


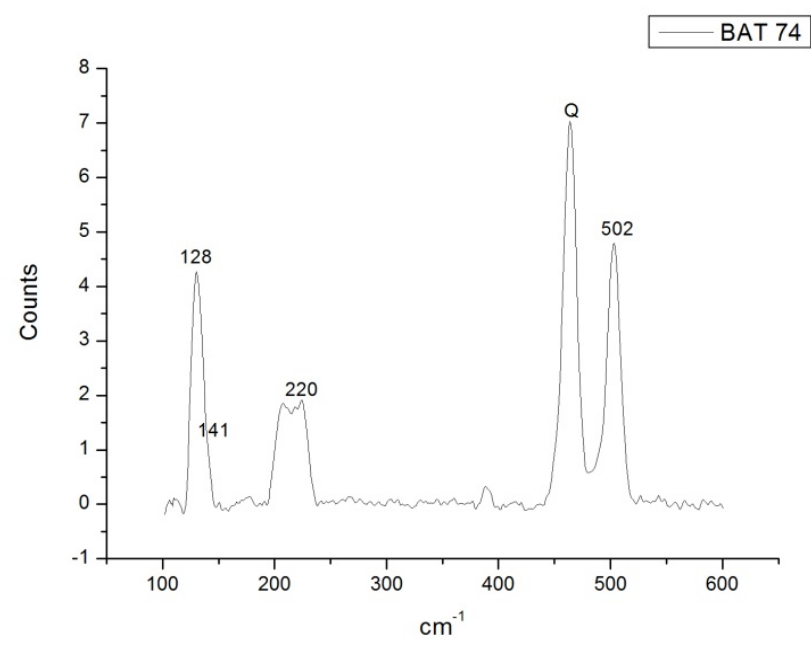

FIGURE 2 Raman spectrum obtained from a calcedonite formed by ageing from opal (sample BAT-74)

\section{RESULTS}

Optical microscopy has distinguished the varieties of chalcedony and their origin by

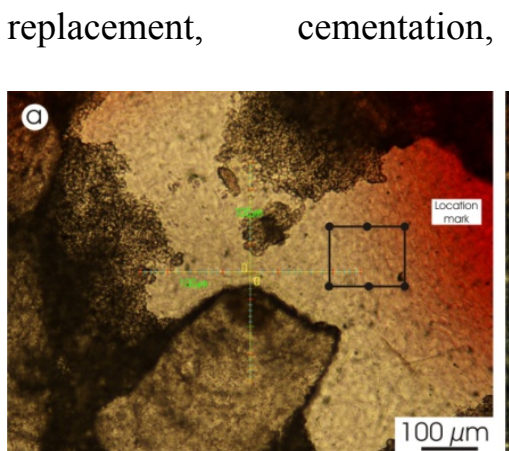

or ageing from

opal (Figure

$3)$.
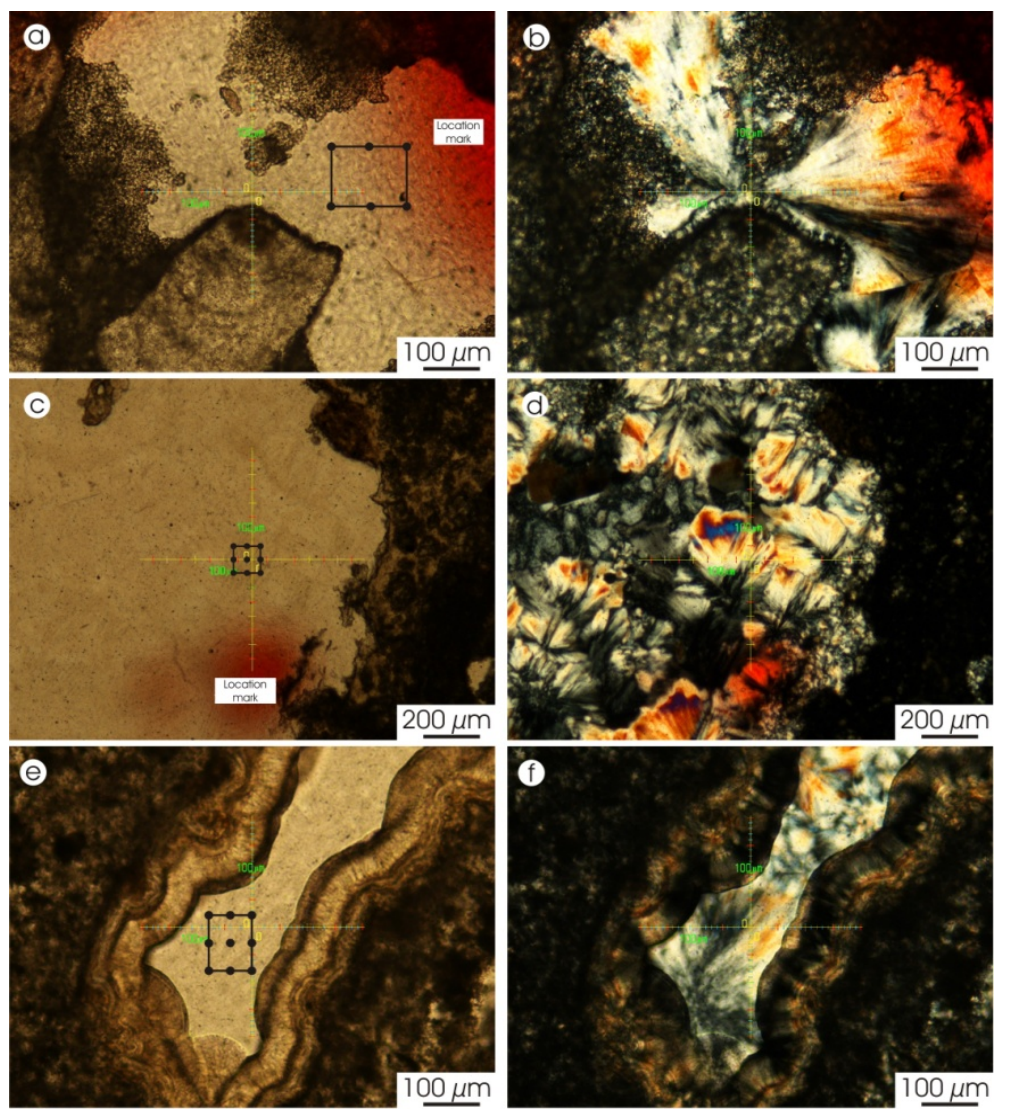
FIGURE 3 Thin section photomicrographs of some of the selected zones studied. (a) Calcedonite aged from opal present in an opaline chert (BAT-74 sample). Plane polarized light. (b) Idem cross-polarized light. (c) Lutecite formed by ageing from the opal present in an opaline chert ( CMO-4 sample). Plane polarized light. (d) Idem, cross-polarized light. (e) Pore cemented with an opaline fibrous-rim cement (lussatite) and afterward, with calcedonite (ESQ-11 sample). Plane polarized light. (f) Idem, cross-polarized light. The superimposed network in a, c and e shows the location of the spots analyzed.

In cases of varieties of chalcedony (some lutecites and calcedonites) interconnected with opal, their formation was attributed to recrystallization of opal (ageing). (Figures 2a, 2b, 2c and 2d). Lack of opal may indicate that the chalcedony was formed directly by replacement of the host rock. Finally the chalcedony varieties included in voids are considered cements (Figure 2e and 2f). It is not possible to identify moganite by its optical properties, ${ }^{[13]}$ which may explain the scarcity of references to moganite in silcretes.

Moganite Raman spectra show bands at 128, 141, 220, and $502 \mathrm{~cm}^{-1}$. The latter peak is the most intense (Figure 2). After 250 spots were analyzed, all the studied varieties of chalcedony (calcedonite, quartzine and lutecite) were observed to contain moganite. The moganite/quartz ratios, in percentages, (intensity of peak 502 of moganite divided by the intensity of peak 465 of quartz), the quartz textures and their genesis are shown in Table 1.

\begin{tabular}{|c|c|c|c|c|c|c|c|c|}
\hline Sample & $\begin{array}{l}\text { Genesis of } \\
\text { silica rock } \\
\text { (Sedimentary } \\
\text { setting) }\end{array}$ & Zone & $\begin{array}{c}\mathbf{N}^{\circ} \text { of } \\
\text { analysis }\end{array}$ & Textures & $\begin{array}{l}\text { Texture } \\
\text { Génesis }\end{array}$ & $\begin{array}{c}\text { Min-Max } \\
\text { Mo/Qtz (\%) } \\
\text { and notes }\end{array}$ & $\begin{array}{c}\text { Mean of } \\
\text { Mo/Qtz } \\
(\%)\end{array}$ & $\begin{array}{c}\text { Stand. } \\
\text { deviat. }(\sigma) \\
\text { Mo/Qtz }(\%)\end{array}$ \\
\hline \multirow{7}{*}{$\begin{array}{c}\text { CMO-4 } \\
\text { Opaline } \\
\text { chert }\end{array}$} & \multirow{7}{*}{$\begin{array}{l}\text { Silicif. } \\
\text { Mudstone } \\
\text { (palustrine/ } \\
\text { lacustrine) }\end{array}$} & 1 & 4 & Lutecite & Ageing & $20-44$ & 41 & 6 \\
\hline & & 2 & 9 & Lutecite & Ageing & $37-49$ & 30 & 7 \\
\hline & & 3 & 1 & Calcedonite & Cement & Only Qtz & & \\
\hline & & 4 & 4 & Clear opal & Cement & Flat Spectra & & \\
\hline & & 5 & 4 & $\begin{array}{c}\text { Dark opal } \\
\text { Microcrystalline }\end{array}$ & Replacement & Flat Spectra & & \\
\hline & & 6 & 6 & Qtz. & Ageing & $30-36$ & 33 & 3 \\
\hline & & 7 & 9 & Lutecite & Ageing & $19-30$ & 26 & 3 \\
\hline
\end{tabular}




\begin{tabular}{|c|c|c|c|c|c|c|c|c|}
\hline \multirow{4}{*}{$\begin{array}{l}\text { BAT-74 } \\
\text { Opaline } \\
\text { chert }\end{array}$} & \multirow{4}{*}{$\begin{array}{l}\text { Silicif. } \\
\text { limestone } \\
\text { (calcrete) }\end{array}$} & 1 & 6 & Calcedonite & Ageing & $56-77$ & 68 & 7 \\
\hline & & 2 & 10 & Calcedonite & Cement & $37-41$ & 39 & 2 \\
\hline & & 3 & 9 & Calcedonite & Cement & $22-39$ & 36 & 5 \\
\hline & & 4 & 17 & Qtz. & Cement & Only Qtz & & \\
\hline \multirow{5}{*}{$\begin{array}{c}\text { ESQ-11 } \\
\text { Opaline } \\
\text { chert }\end{array}$} & \multirow{5}{*}{$\begin{array}{c}\text { Silicif. } \\
\text { limestone } \\
\text { (shallow } \\
\text { lacustrine) }\end{array}$} & 1 & 9 & Calcedonite & Ageing & $32-38$ & 35 & 2 \\
\hline & & 2 & 9 & Calcedonite & Cement & $53-70$ & 65 & 5 \\
\hline & & 3 & 4 & Opal (Lussatite) & Cement & Flat Spectra & & \\
\hline & & 4 & 6 & $\begin{array}{l}\text { Qtz. } \\
\text { Microcrystalline }\end{array}$ & Ageing & $14-30$ & 25 & 6 \\
\hline & & 5 & 17 & Qtz. & Ageing & $22-49$ & 37 & 6 \\
\hline \multirow{3}{*}{$\begin{array}{c}\text { BRI-12 } \\
\text { Chert }\end{array}$} & \multirow{3}{*}{$\begin{array}{c}\text { Silicif. } \\
\text { limestone } \\
\text { (palustrine) }\end{array}$} & 1 & 10 & Calcedonite & Replacement & $33-35$ & 34 & 1 \\
\hline & & 2 & 9 & Qtz. & Replacement & $25-31$ & 29 & 2 \\
\hline & & 3 & 8 & Calcedonite & Cement & $35-38$ & 36 & 1 \\
\hline \multirow{4}{*}{$\begin{array}{l}\text { PISCI-3B } \\
\text { Chert }\end{array}$} & \multirow{4}{*}{$\begin{array}{l}\text { Silicif. gypsum } \\
\text { (palustrine) }\end{array}$} & 1 & 3 & $\begin{array}{l}\text { Qtz:Fibrous } \\
\text { nuclei }\end{array}$ & Replacement & Only Qtz & & \\
\hline & & 2 & 9 & Petaloidal Qtz & Replacement & Only Qtz & & \\
\hline & & 3 & 9 & Qtz. & Replacement & Only Qtz & & \\
\hline & & 4 & 4 & Lutecite & Replacement & $31-36$ & 34 & 2 \\
\hline \multirow{5}{*}{$\begin{array}{l}\text { CC-2 } \\
\text { Chert }\end{array}$} & \multirow{5}{*}{$\begin{array}{c}\text { Silicif. } \\
\text { dolostone } \\
\text { (palustrine) }\end{array}$} & 1 & 10 & Quartzine & Replacement & Only Qtz & & \\
\hline & & 2 & 11 & $\begin{array}{c}\text { nuclei } \\
\text { Quartzine: clear }\end{array}$ & Replacement & $37-42$ & 39 & 2 \\
\hline & & 3 & 9 & border & Replacement & Only Qtz & & \\
\hline & & 4 & 9 & Quartzine & Replacement & Only Qtz & & \\
\hline & & 5 & 9 & $\begin{array}{l}\text { Microcrystalline } \\
\text { Qtz. }\end{array}$ & Replacement & $27-34$ & 31 & 2 \\
\hline \multirow{5}{*}{$\begin{array}{l}\text { MDX-18 } \\
\text { Chert }\end{array}$} & \multirow{5}{*}{$\begin{array}{c}\text { Silicif. } \\
\text { dolostone } \\
\text { (palustrine) }\end{array}$} & 1 & 10 & Lutecite & Replacement & $48-55$ & 52 & 3 \\
\hline & & 2 & 9 & Calcedonite & Replacement & $36-55$ & 47 & 7 \\
\hline & & 3 & 4 & Quartzine & Replacement & $31-36$ & 34 & 2 \\
\hline & & 4 & 4 & Calcedonite & Replacement & $45-47$ & 46 & 1 \\
\hline & & 5 & 4 & Lutecite & Replacement & $54-59$ & 57 & 2 \\
\hline \multirow{3}{*}{$\begin{array}{c}\text { S-4 } \\
\text { Chert }\end{array}$} & \multirow{3}{*}{$\begin{array}{c}\text { Silicif. } \\
\text { Dolostone } \\
\text { (palustrine) }\end{array}$} & 1 & 18 & Lutecite & Replacement & $26-82$ & 51 & 14 \\
\hline & & 2 & 8 & Qtz. & Replacement & Only Qtz & & \\
\hline & & 3 & 1 & Calcedonite & Replacement & 40 & & \\
\hline
\end{tabular}

The values of each variety of chalcedony can change very much, even in the same analyzed network (e.g. in lutecite it varies from 26 to $82 \%$ or in calcedonite from 36 to $55 \%$ ). Therefore, every studied chalcedony will be composed of alternating quartz and moganite domains in all three dimensions, with variable domain sizes. But also these variations can be due to the different orientation of the analyzed section. Moganite was always absent from the macrocrystalline and mesocrystalline quartz, and occasionally from quartzine formed by replacement as well as from some calcedonite cements. When different replacement 
chalcedony varieties are found in the same sample, the lutecite shows the highest values of moganite/quartz ratios (48-55\%), followed by calcedonite (36-55\%) and quartzine (31-36\%). When quartzines are not well formed and consist of fibrous or microcrystalline nuclei, and external parts formed of elongated and interpenetrated megaquartz/mesoquartz crystals, then moganite is only recognised in the nuclei. The opaline zones produce flat spectrums with no moganite peaks, but when microcrystalline mosaic quartz is seen in optical microscopy, moganite peaks are found.

Calcedonite (length-fast fibrous form) is pervasive in the carbonate sedimentary settings lacking dolomite or gypsum. The presence of moganite in calcedonite is variable, with a higher variation of moganite/quartz ratio in calcretes (22-77\%) and shallow lacustrine limestones (32$70 \%)$ than in palustrine limestones (33-38\%), although these data might only be a consequence of the orientation of analyzed sections. The effect of ageing from opal or cementation on the moganite/quartz ratios in the above settings could not be distinguished. Length-slow fibrous forms (lutecite and quartzine) are dominant in the palustrine evaporitic and Mg-rich settings (with gypsum and dolomite-magnesic clays respectively). In these settings length-slow fibrous forms have the highest variation in the moganite/quartz ratio (26-82\%).

\section{CONCLUSIONS}

Our results show that all the varieties of chalcedony (calcedonite, quartzine and lutecite) can have a composite Raman spectrum of both quartz and moganite, independent of their genesis by ageing, direct replacement or cementation. The presence of moganite is also independent of the near-surface sedimentary setting of the host rocks in which the silcrete is formed.

\section{ACKNOWLEDGMENTS}

Financial support was provided by projects CGL2008-05584-CO2-01 and 02, from the Spanish Ministry of Science and Innovation. 


\section{REFERENCES}

1. Pérez-Jiménez, J.L. Sedimentología, silicificaciones y otros procesos diagenéticos en las unidades Intermedia y Superior del Mioceno de la Cuenca de Madrid (zonas NE, NW y W): Madrid, Facultad de Geológicas, Universidad Complutense, tesis doctoral, 2010, $336 \mathrm{pp}$.

2. Nash, D. J.; Hopkinson, L.A reconnaissance laser Raman and Fourier transform infrared survey of silcretes from the Kalahari Desert, Botswana. Earth Surface Process and Landforms 2004, 29, 1541-1558.

3. Miehe, G.; Graetsch H. Crystal structure of moganite: a new structure type for silica. European Journal of Mineralogy 1992, 4, 693-706.

4. Heaney,P.J. Moganite as an indicator for vanished evaporites: a testament reborn?. Journal of Sedimentary Research 1995, 65A: 633-638.

5. Bustillo, M. A. Aparición y significado de la moganita en rocas de la sílice: Una revisión. Journal of Iberian Geology 2002, 28, 157-166.

6. Moxon, T.; Nelson, D. R. ; Zhang M. Agate recrystalisation: evidence from samples found in Achaean and Proterozoic host rocks, Western Australia, Australian Journal of Earth Sciences 2006, 53, 235-248.

7. Jones, J. B.; Segnit, E. R. The nature of opal, I: nomenclature and constituent phases, Journal of the Geological Society of Australia, 1971, 18, 57-68.

8. Rodgers, K.A.; Hampton, W.A. Laser Raman identification of silica phases comprising microtextural components of sinters. Mineralogical Magazine 2003, 67, 1-13.

9. Lynne, B.Y.; Campbell, K.A.; Moore, J.N.; Browne, P.R.L. Diagenesis of 1900-year-old siliceous sinter (opal-A to quartz) at Opal Mound, Roosevelt Hot Springs, Utah, U.S.A. Sedimentary Geology 2005, 179, 249-278.

10. Alonso-Zarza, A.M.; Armenteros, I.; Braga, J.C.; Muñoz, A.; Pujalte J. In The Geology of Spain, Tertiary; Gibbons, W.; Moreno, T., Ed.; The Geological Society: London, 2002, pp. 293-334.

11. Götze J.; Nasdala L.; Kleeberg R.; Wenzel M. Occurrence and distribution of "moganite" in agate/chalcedony: a combined micro-Raman, Rietveld, and cathodoluminescence study. Contributions to Mineralogy and Petrology, 1998,133, 96-105.

12. Parthasarathy, G.; Kunwar, A.C.; Srinivasan, R. Occurrence of moganite-rich chalcedony in Deccan flood basalts, Killari, Maharashtra, India. European Journal of Mineralogy 2001, 13, 127-134.

13. Bustillo, M. A. Cherts with moganite in continental Mg-clay deposits: an example of "false" magadi-type cherts, Madrid Basin, Spain. Journal of Sedimentary Research 2001, 71 (3), 436-443. 